\title{
POPULATION DYNAMICS AND SPATIAL DISTRIBUTION OF Panaphis juglandis (Goeze, 1778) (Hemiptera: Aphididae) ON COMMON WALNUT (Juglans regia L.)
}

\section{DYNAMIKA POPULACJI I ROZKŁAD PRZESTRZENNY Panaphis juglandis (Goeze, 1778) (Hemiptera: Aphididae) NA ORZECHU WŁOSKIM (Juglans regia L.)}

Department of Biochemistry and Molecular Biology, Siedlce University of Natural Sciences and Humanities, Poland

\begin{abstract}
Streszczenie. W Polsce orzech włoski ze względu na swój pokrój i okazałe liście zdobył uznanie jako drzewo zdobiące otaczającą nas przestrzeń. Celem pracy było prześledzenie rozkładu przestrzennego Panaphis juglandis (Goeze) zasiedlającej drzewa Juglans regia L. w różnych siedliskach, w odniesieniu do warunków pogodowych. Badania prowadzono na orzechu włoskim (Juglans regia L.) w Siedlcach w latach 2010-2012. Do obserwacji wytypowano trzy stanowiska w ogrodach przydomowych $(\mathrm{H} 1, \mathrm{H} 2, \mathrm{H} 3)$ oraz jedno stanowisko przyuliczne $(\mathrm{H} 4)$. Badania wykazały, że więcej populacji szkodnika występowało w miejskich zadrzewieniach w pobliżu ulic, niż w przypadku badanych drzew z ogrodów przydomowych. $P$. juglandis zawsze występowała na górnej stronie liści złożonych orzecha włoskiego i formowała kolonie $w$ pobliżu nerwu głównego tylko na pierwszych trzech zewnętrznych listkach w liściu złożonym orzecha włoskiego.
\end{abstract}

Key words: aphids, Panaphis juglandis, walnut, population dynamics.

Słowa kluczowe: mszyce, Panaphis juglandis, orzech włoski, dynamika populacji.

\section{INTRODUCTION}

Walnut (Juglans regia L.) tree cultivation is widely distributed around of Northern Hemisphere. Common walnut is one of the most cultivated species throughout Northern Africa, Eastern Asia and Southern Europe. This species grows well in virtually all parts of the world with a temperate climate. Recently, there has been an increasing demand for walnut since its nuts are considered one of the most nutritional and healthy food (Christopoulos and Tsantili 2015; Copolovici et al. 2017; Pollegioni et al. 2017). Thus the tree has great socioeconomic importance being frequently cultivated in temperate zones of the world mainly because of its oil is rich in unsaturated fatty acids, phytosterols and tocopherols (Amaral et al. 2003, 2005) and whose consumption has been recently related to health benefits (Sabaté et al. 1993; Anderson et al. 2001; Fukuda et al. 2004). Moreover, its non-edible parts such as

Corresponding author - Adres do korespondencji: Robert Krzyżanowski, Department of Biochemistry and Molecular Biology, Siedlce University of Natural Sciences and Humanities, Bolesława Prusa 12, 08-110 Siedlce, Poland, e-mail: robert.krzyzanowski@uph.edu.pl 
leaves, husks and wood also find broad application as flavour liqueurs (Jakopic et al. 2007), cosmetics (Tsamourisa et al. 2002), dyes (Park et al. 2005), furniture and in traditional medicine product (Amaral et al. 2008).

Walnut leaf has been widely used in folk medicine for treatment of venous insufficiency and haemorrhoidal symptomatology, and for its antidiarrheic, antihelmintic, depurative and astringent properties (Bruneton 1993). Keratolytic, antifungal, hypoglycaemic, hypotensive, anti-scrofulous and sedative activities have been also described. Several of these traditionally attributed actions may be due to tannins known to occur in these leaves, but also to several phenolic compounds (Amaral et al. 2008). Among then phenolic acids, flavonoids and naphthoquinones are the most important phenolic compounds within walnut leaf tissues (Jakopic et al. 2008; Chrzanowski et al. 2011; Nour et al. 2013). In fact, several pharmacological effects have been ascribed to flavonoids, such as anti-inflammatory, antihepatotoxic, antitumor, antimicrobial, antiviral, and enzyme inhibition (Cai et al. 2004).

Two species of aphids colonize walnut, large walnut aphid Panaphis juglandis (Goeze 1778) and small walnut walnut aphid Chromaphis juglandicola (Kaltenbach 1843) (Jaśkiewicz and Kmieć 2007; Karczmarz 2012; Leszczyński et al. 2012; Wani and Ahmad 2014; Krzyżanowski 2017). Walnut aphid is native to the Old World and invaded California at the beginning of the 20th century. It is supposed that its homelands were Central Asia and South-Eastern Europe. Distribution of this tree includes a narrow but quite long strip of land, passing through Asia Minor, Persia, Caucasus, along the Himalayas through Tibet, up to China (Debach 1974; Karczmarz 2010).

$P$. juglandis has been also widely known under the name of Callaphis juglandis, but the generic name Callaphis Walker has been suppressed by the opinion No. 147 of the ICZN following the plea of Quednau (1983) on the grounds of potential confusion with Callaphis Walsh. The species was originally described from Germany (Goeze 1778), and it is common throughout Europe from Spain (Nieto Nafría and Mier Durante 1998), Italy (Barbagallo et al. 1995), Serbia (Petrovič 1998) to Denmark, Sweden (Heie 1982) and Poland (Szelęgiewicz 1972). P. juglandis colonize only the top side of the walnut leaf, establishing characteristic colonies along the main vascular vein (Jaśkiewicz and Cichocka 2004), but Ch. juglandicola was observed on the bottom part of the leaf blade (Jaśkiewicz 2003; Krzyżanowski 2017). $P$. juglandis is much larger than the $C h$. juglandicola and works entirely on the upper surface of leaves while Chromaphis feeds on lower surface of the walnut leaves. Both aphids are phloem feeders and reduce tree vigour, nut size, yield, and its quality. In addition to direct feeding damage, they excrete copious amounts of honey-dew that falls onto nuts, leaves and shoots. Honey-dew supports growth of the black sooty mould fungus. This fungus reduces light penetration to the leaf surface and reducing its photosynthetic capacity. Being black, it also absorbs heat to predispose nuts to sunburn and subsequent kernel quality loss due to high temperatures. High populations of the aphids may also cause leaf drop, and exposing more nuts to sunburn. If heavy populations are allowed to develop (i.e. > 15 aphids per walnut leaflet) and remain for at list 14 days uncontrolled, current season's nut quality is reduced along with a substantial reduction in the following season's crop (Wani and Ahmad 2014). 
There is no data in the literature on the detailed spatial distribution of the large walnut aphid on leaflets in walnut composite leaf. The aim of three-year studies was to establish the population dynamics and spatial distribution of $P$. juglandis settling the different leaflets on composite leaf in trees of $J$. regia in Siedlce stands.

\section{MATERIAL AND METHODS}

Studies were conducted in the area of Siedlce during 2010-2012. Four observation trees of $J$. regia were designated:

A. Home gardens location - situated in a single family housing estate $(\mathrm{H} 1, \mathrm{H} 2, \mathrm{H} 3)$.

B. The street-side location was situated at the crossing of busy roads $(\mathrm{H} 4)$.

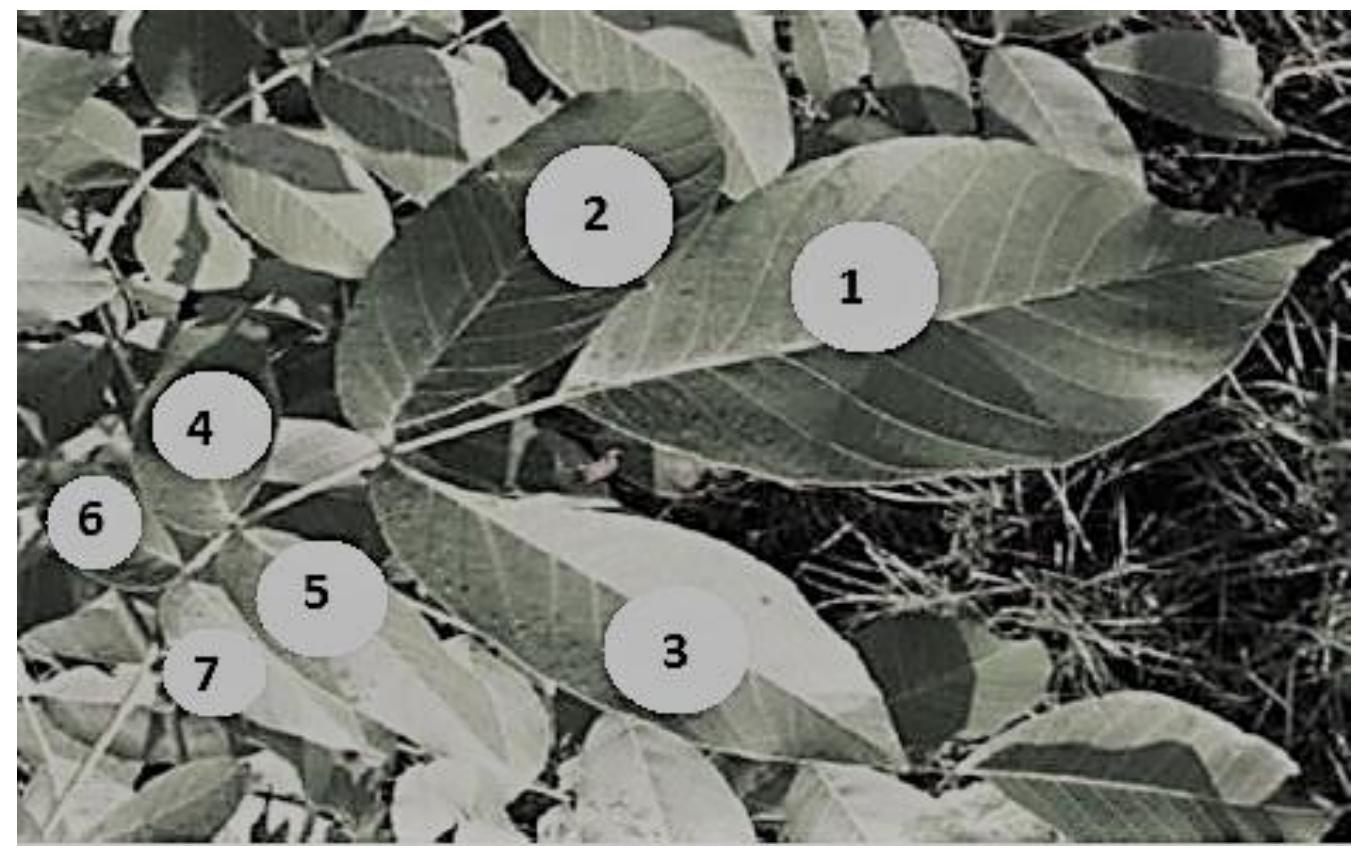

Fig. 1. Diagram of leaflets in composite leaf of walnut Source: after Krzyżanowski (2017).

Ryc. 1. Schemat oznaczenia pojedynczych listków w liściu złożonym orzecha włoskiego Źródło: wg Krzyżanowskiego ( 2017).

In each of the selected stands a sample of 25 composite leaves was collected. The samples were taken every 10 days from May to September. The collected material was viewed in a laboratory, under a stereoscopic microscope. Identification of this aphid as to species was conducted on the basis of durable slides. Blacman and Eastop (2000) and Cichocka (1980) keys were used for determinations.

Results were the basis for the determination spatial distribution of $P$. juglandis for leaflets, which are marked with the following symbols 1-7 (Fig. 1). Results for the individual dates are presented in the form of the average number of aphids per composite leaf of walnut.

Whether conditions (temperature, relative humidity) in year 2010-2012 were measurement by Kestrel 4000 (Nielsen-Kellerman, USA) with Kestrel Communicator Software ver.2.5/2014 (Nielsen-Kellerman, USA) - Fig. 5-6. 


\section{RESULTS}

During the 2010, a single specimens of $P$. juglandis appeared on stand $\mathrm{H} 4$ at the first decade of May. At the home garden stands $\mathrm{H} 1-\mathrm{H} 3$, the first single specimens of plant lice was observed in the third decade of May (Fig. 4), and always development of the aphid population started on external leaflets (1-4). At the $\mathrm{H} 4$ street stand a higher number of alatae females occurred between the first and the third decade of May (leaflets 1-2). Moderately warm May up to the first decade June $\left(15-20^{\circ} \mathrm{C}\right)$, with an average rainfall, enhanced development of the aphid population (Fig. 2).

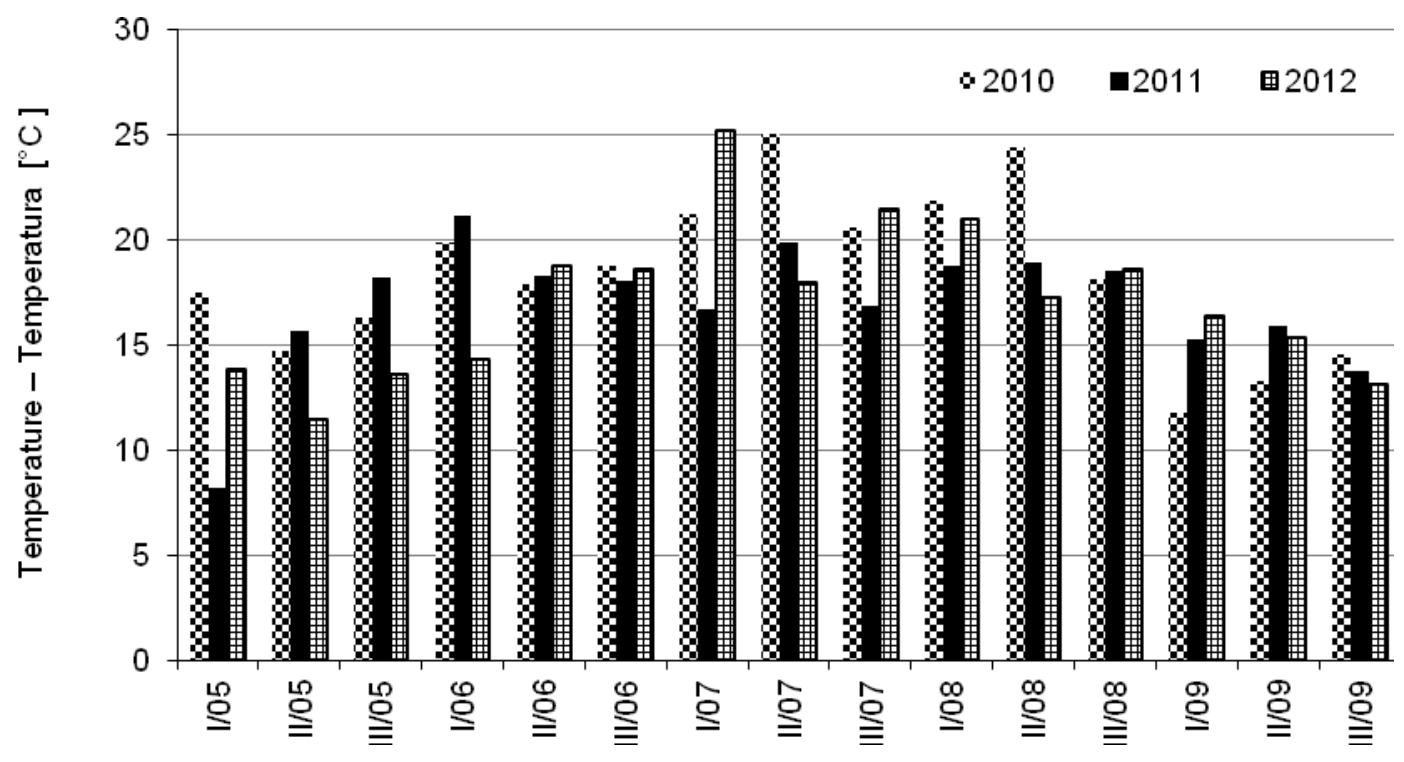

Observation time - Czas obserwacji (decade of month - dekady miesiąca)

Fig. 2. Temperature measurement in the years 2010-2012

Ryc. 2. Pomiar temperatury w latach 2010-2012

Next, the number of the aphids suddenly increased and the peak population, was reported in the second decade of June for $\mathrm{H} 4$ stand and third decade of June for $\mathrm{H} 1$ stand (Fig. 4). The home garden stands showed a higher number of alatae females during the first decade of June on three first external leaflets. In the subsequent observations, when the temperature increased up to $25^{\circ} \mathrm{C}$ and the rainfall was more intensive, the number of plant lice significantly decreased to third decade of July and in the first decade of August no aphids were found to be present on the leaves of $J$. regia in the home garden trees (Fig. 2). P. juglandis stayed on the examined tree $\mathrm{H} 4$ to third decade of August and remained on the tree to second decade of September. In third decade of September, decrease at high temperatures (less than $15^{\circ} \mathrm{C}$ ), no aphids were observed on the examined four leaflets (1-4) (Fig. 4).

Since the early start of vegetation, in the year 2011, the first apterae of $P$. juglandis were found on stand $\mathrm{H} 2$ in the third decade of April. Then, cool spring (temperature about $7^{\circ} \mathrm{C}$ ), with low level of precipitation and persistent in a given period of constant humidity (about 
80\%) appeared (Fig. 3). It stopped development of the aphid population on the stand $\mathrm{H} 1-\mathrm{H} 3$, but on suddenly increased on the stand $\mathrm{H} 4$ on the all studied leaflets (1-4). The peak population occurred, when the temperature was less than $20^{\circ} \mathrm{C}$, in all examined trees at the second decade of June (Fig. 5). In the next 10-days period the aphid population radically decreased. Finally, the last specimens of $P$. juglandis were reported in the third decade of August $(\mathrm{H} 1-\mathrm{H} 3)$. However, the aphids detected in $\mathrm{H} 4$ stand were still present there August and the up to the second decade of September, when the temperature decreased to about $15^{\circ} \mathrm{C}$ (Fig. 2-3).

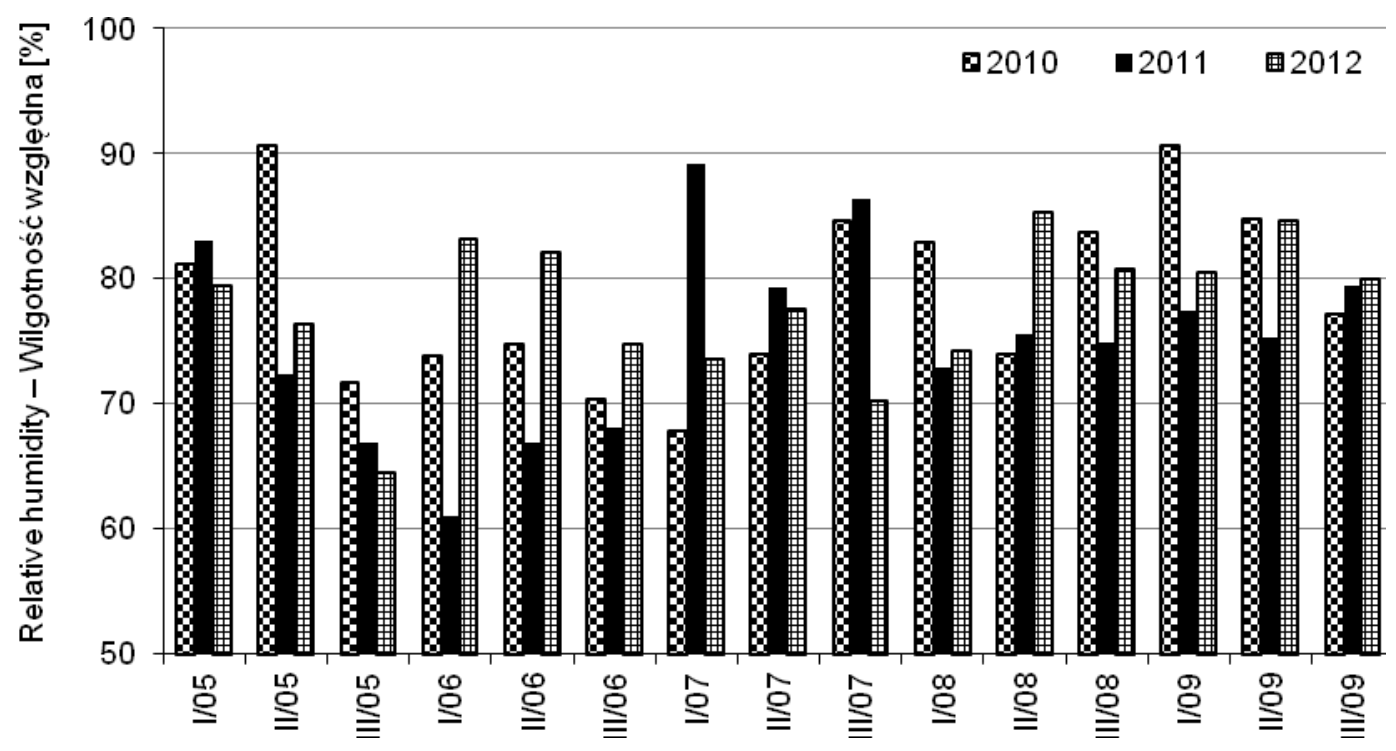

Observation time - Czas obserwacji (decade of month - dekady miesiąca)

Fig. 3. Relative humidity conditions during 2010-2012

Ryc. 3. Pomiar względnej wilgotności w latach 2010-2012

In the last year of the observations (2012), the first aphids on the $\mathrm{H} 4$ trees was observed in the first decade of May (Fig. 6), instead the highest number of alatae females occurred there between the third decade of April and the first decade of June (leaflets 1-3). Maximum of the aphid populations were observed at the second decade of June $(\mathrm{H} 1-\mathrm{H} 3$ stands) on first external leaflets (1) and in $\mathrm{H} 4$ tree on three leaflets (1-3). In subsequent observations the population of $P$. juglandis significantly decreased and systematically was reduced up to third decade July. Results of the observations were seriously affected by weather conditions, including such decrease in level of precipitation and humidity during the third decade of July, and increase of daily temperature up to $20^{\circ} \mathrm{C}$ between the second and the third decade of July (Fig. 2-3). At the beginning of August aphid population radically decreased. However, when the daily temperature decreased (temperature under $20^{\circ} \mathrm{C}$ ), the second peak of the walnut aphid population appeared at the third decade of August (stands $\mathrm{H} 1$ and $\mathrm{H} 4$ ), on four leaflets (1-4) (Fig. 6). The followed observations between August and September showed further decrease of daily temperature and decrease of aphid number in this (Fig. 2-3). 
H1

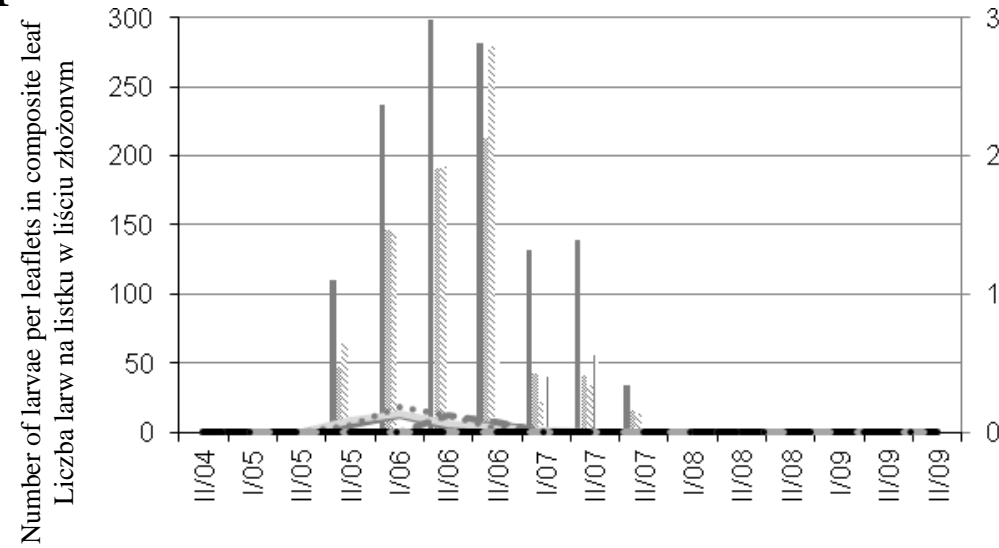

H2

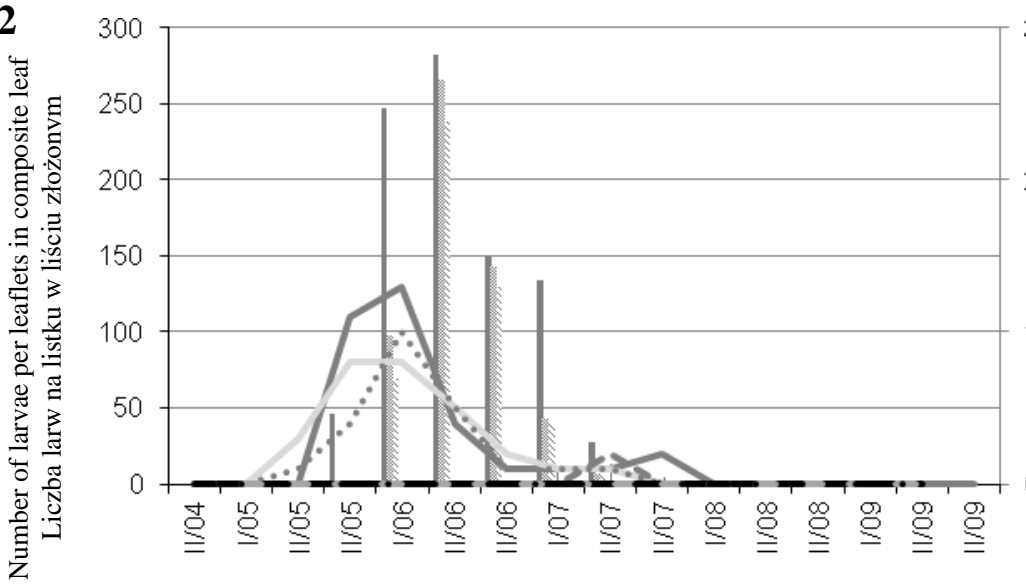

H3

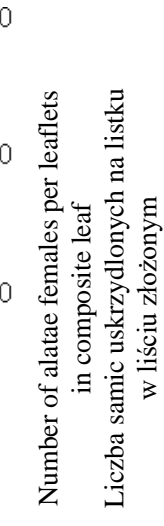

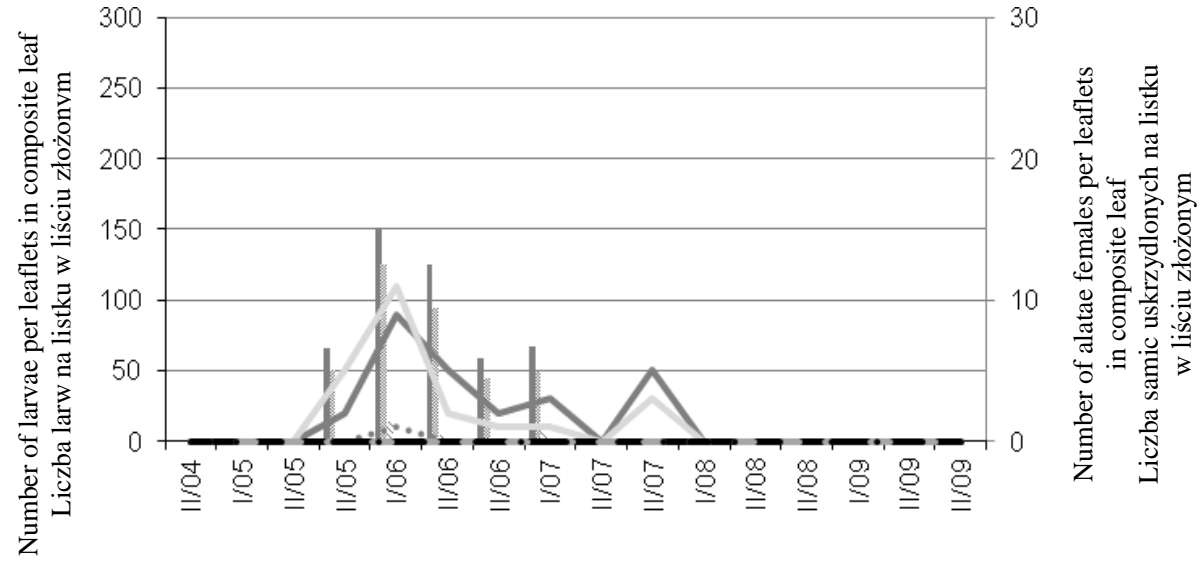

H4

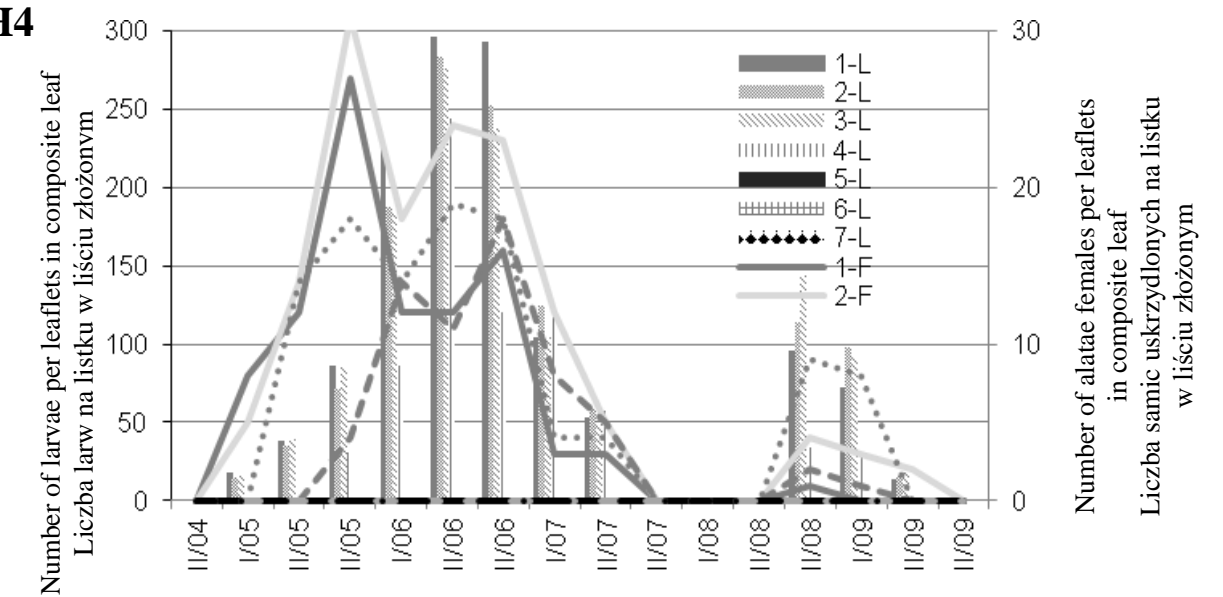

Observation time - Czas obserwacji (decade of month - dekady miesiąca)

Fig. 4. Spatial distribution of Panaphis juglandis population on the examined walnuts H1, H2, H3 and H4 in 2010 (symbol of leaflets $1-\mathrm{L}$, 2-L, 3-L, 4-L, 5-L, 6-L and $7-\mathrm{L}$ relate to spatial distribution of larvae and symbols of leaflets $1-\mathrm{F}, 2-\mathrm{F}, 3-\mathrm{F}, 4-\mathrm{F}, 5-\mathrm{F}, 6-\mathrm{F}$, and 7-F relate to spatial distribution of alatae females)

Ryc. 4. Rozkład przestrzenny Panaphis juglandis na badanych orzechach H1, H2, H3 i H4 w 2010 (oznaczenia listków 1-L, 2-L, 3-L, 4-L, 5-L, 6-L i 7-L dotyczą rozkładu larw na listkach, a oznaczenia listków 1-F, 2-F, 3-F, 4-F, 5-F, 6-F i 7-F dotyczą rozkładu samic uskrzydlonych 
H1

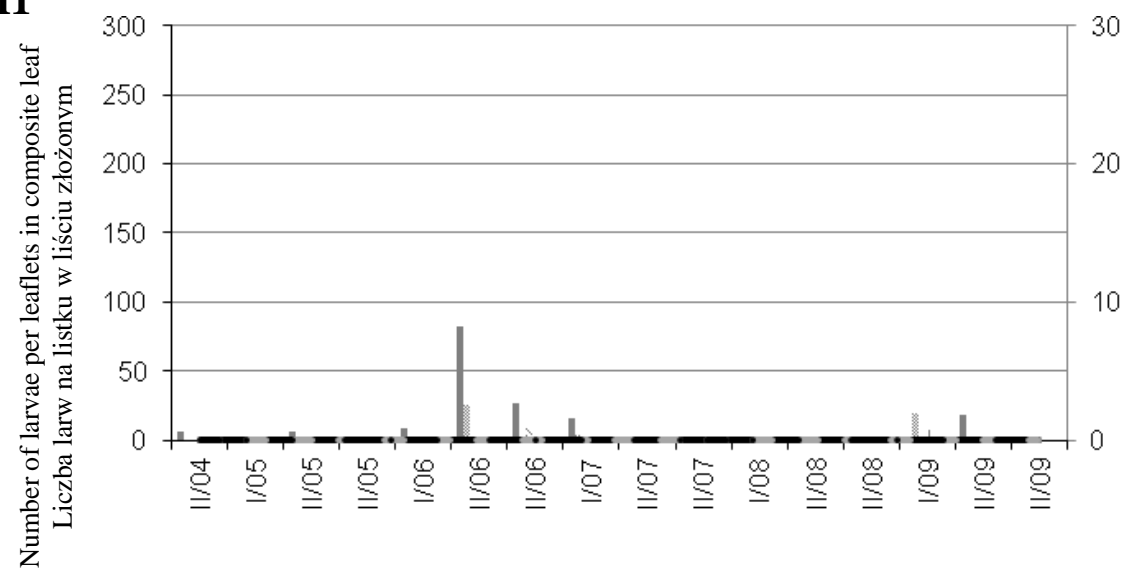

H2

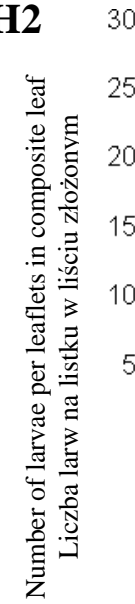

30

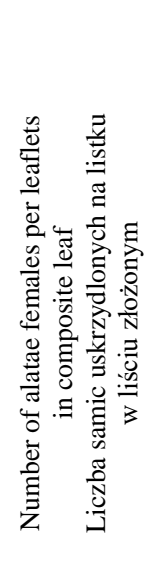

H3

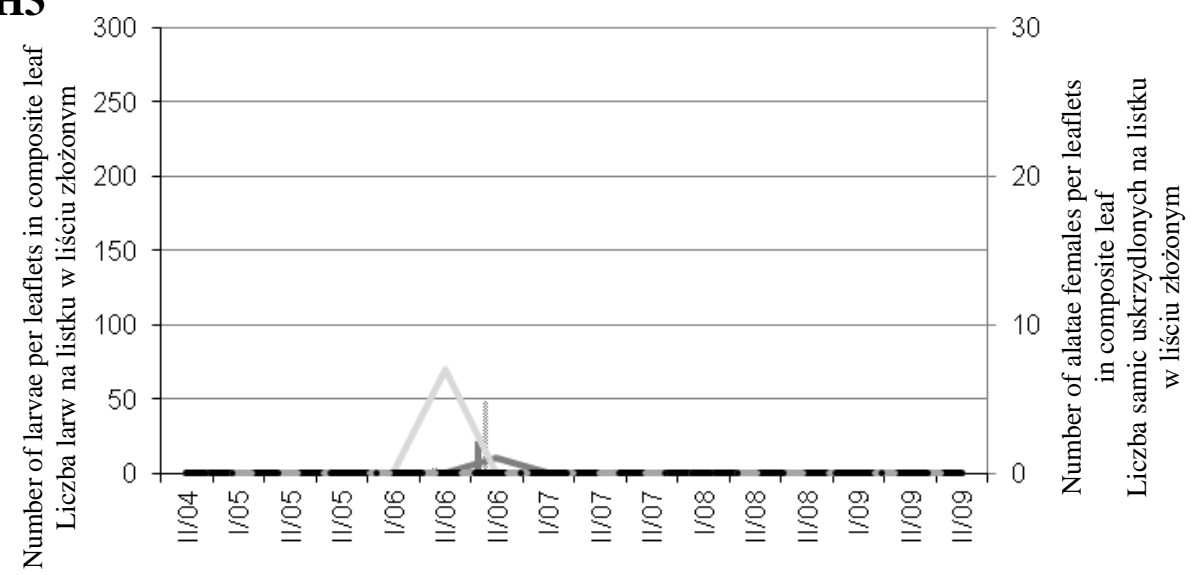

H4

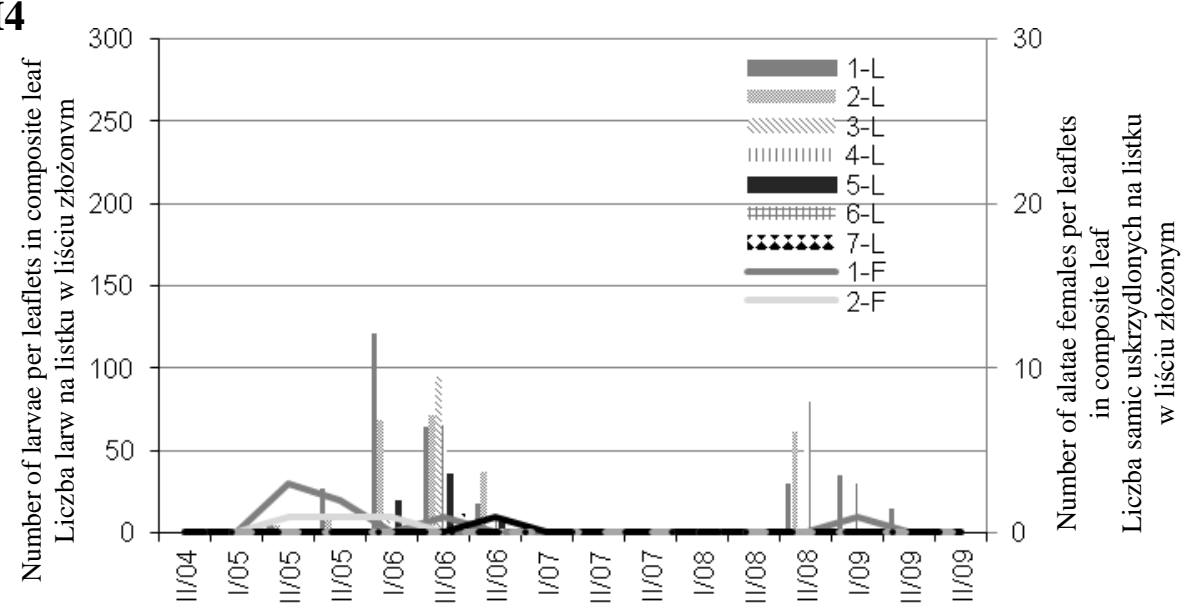

Observation time - Czas obserwacji (decade of month - dekady miesiąca)

Fig. 5. Spatial distribution of Panaphis juglandis population on the examined walnuts H1, H2, H3 and H4 in 2011 (symbol of leaflets 1-L, 2-L, 3-L, 4-L, 5-L, 6-L and 7-L relate to spatial distribution of larvae and symbols of leaflets $1-\mathrm{F}, 2-\mathrm{F}, 3-\mathrm{F}, 4-\mathrm{F}, 5-\mathrm{F}, 6-\mathrm{F}$, and 7-F relate to spatial distribution of alatae females)

Ryc. 5. Rozkład przestrzenny Panaphis juglandis na badanych orzechach H1, H2, H3 i H4 w 2011 (oznaczenia listków 1-L, 2-L, 3-L, 4-L, 5-L, 6-L i 7-L dotyczą rozkładu larw na listkach, a oznaczenia listków 1-F, 2-F, 3-F, 4-F, 5-F, 6-F i 7-F dotyczą rozkładu samic uskrzydlonych 
H1

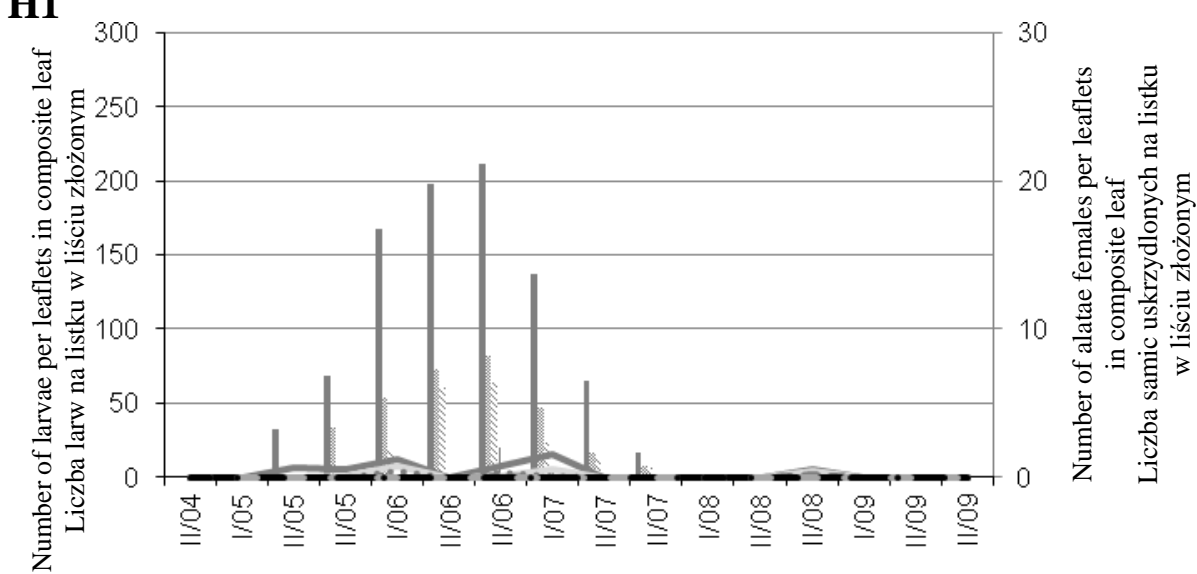

H3

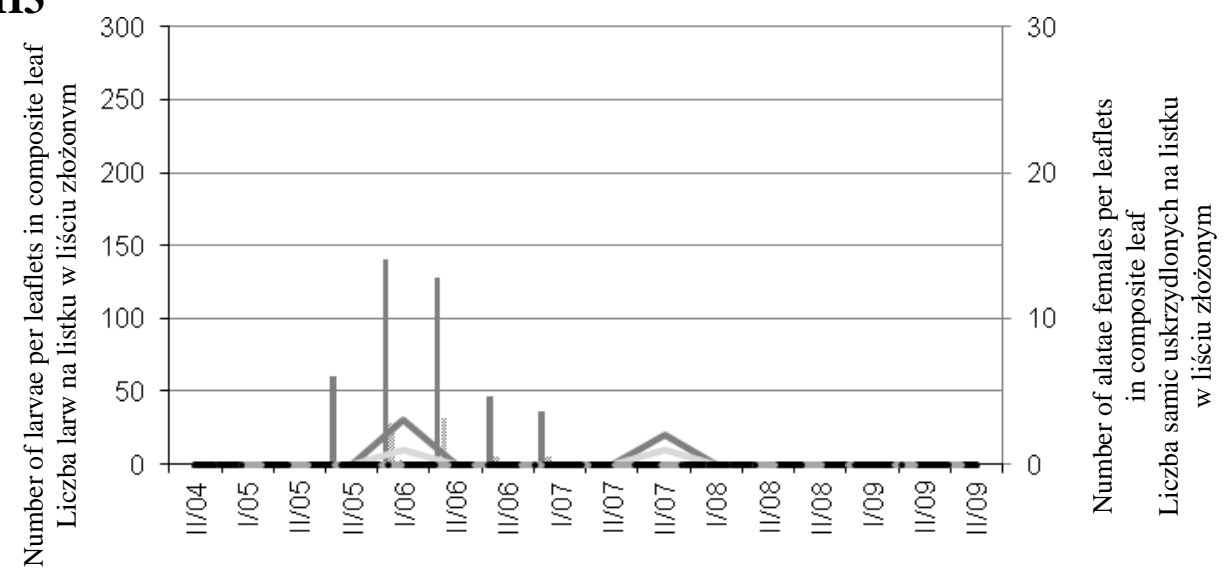

H4

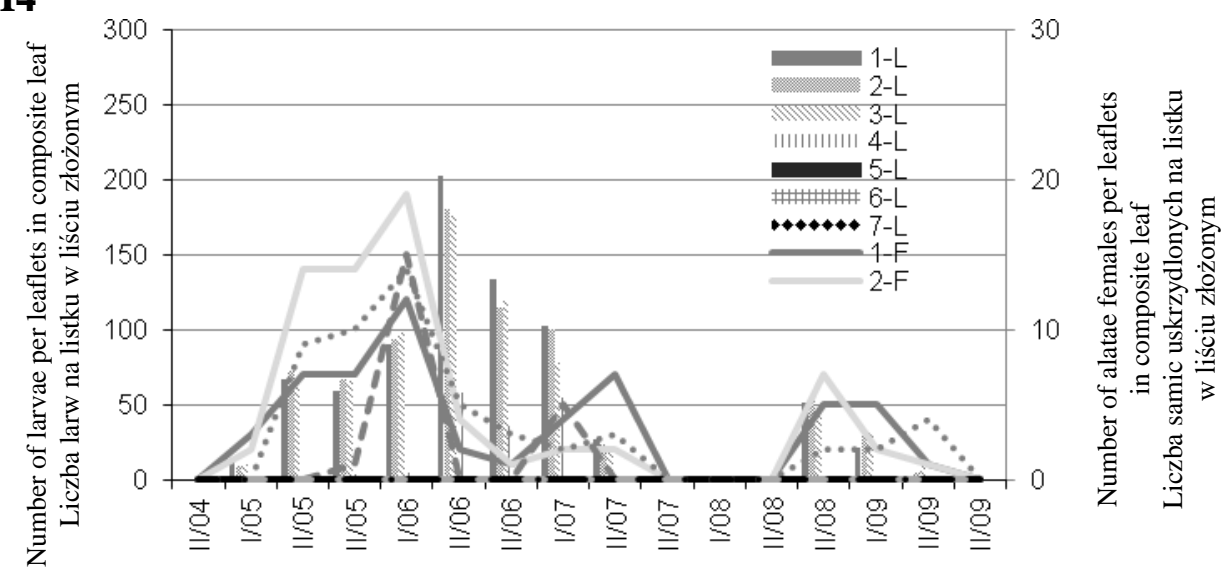

Observation time - Czas obserwacji (decade of month - dekady miesiąca)

Fig. 6. Spatial distribution of Panaphis juglandis population on the examined walnuts H1, H2, H3 and H4 in 2012 (symbol of leaflets 1-L, 2-L, 3-L, 4-L, 5-L, 6-L and $7-\mathrm{L}$ relate to spatial distribution of larvae and symbols of leaflets 1-F, 2-F, 3-F, 4-F, 5-F, 6-F, and 7-F relate to spatial distribution of alatae females)

Ryc. 6. Rozkład przestrzenny Panaphis juglandis na badanych orzechach H1, H2, H3 i H4 w 2012 (oznaczenia listków 1-L, 2-L, 3-L, 4-L, 5-L, 6-L i 7-L dotyczą rozkładu larw na listkach, a oznaczenia listków 1-F, 2-F, 3-F, 4-F, 5-F, 6-F i 7-F dotyczą rozkładu samic uskrzydlonych 


\section{DISCUSSION}

The occurrence of two aphid species was observed on walnut: Panaphis juglandis (Goeze 1778) and Chromaphis juglandicola (Kaltenbach 1843). Aphids $P$. juglandis colonize only the top side of the walnut composite leaf, establishing characteristic colonies along the vascular vein. $P$. juglandis has always been the predominant species on studied stands of walnut in the Siedlce area. Similar results were reported earlier for the Lublin region by Jaśkiewicz and Cichocka (2004), as well as Cichocka (1980). Results of the studies by Krzyżanowski 2016 indicated that sometimes Ch. juglandicola may predominate, as well.

In the present study this aphid was present in each year in the all investigated locations. It occurred in greater number in the street-side stand, which is consistent with the conclusions reached by Cichocka et al. (1998) and Halbert et al. (1998); Milevoj and Kravanja (1999); Wilkaniec (1999); Lubiarz (2009); Karczmarz (2012), reported that insects with stinging-sucking mouthparts occur in greater numbers in the areas that undergo strong anthropopressure.

Panaphis juglandis was feeding on the examined trees from spring to early autumn, and peak density was mostly observed at June. This is consistent with the previous results, published by Jaśkiewicz and Cichocka (2004). However, Jaśkiewicz and Kmieć (2007) report that walnut trees during 2003-2005 were mostly infested by the aphids between June and July.

Based on the conducted observations it was shown that development of $P$. juglandis population on composite leaf of the walnut began on external leaflets. Next the $P$. juglandis spreads on the all leaflets of the walnut. In addition, Olson (1974) has shown that shortly after the aphids began building up their population on the leaflets, darkening of the midrib occurred. Such discoloration remains distinct even after the aphid colonies have gone. The significance of this discoloration was investigated by examining thin cross sections of midrib with the aid of light microscope. This examination revealed that the discoloration extended into the conductive tissues of the leaflet. However, Krzyżanowski (2017), reported that average length of individual leaflets was the largest in external leaflets. Other leaflets the maximum size attained in the second and third decade of June.

The dynamics of $P$. juglandis population was also significantly affected by the course of whether conditions. Among the studied whether factors, such as daily temperature, humidity and rainfall, the temperature was the most important in development of the walnut aphid population. There was a strong positive correlation between daily temperature and number of the $P$. juglandis on the walnut trees. The weather conditions, including temperature and humidity have been also reported earlier as important factors affecting development of the large walnut aphid (Karczmarz 2012) and common walnut aphid (Karczmarz 2010, 2012).

\section{RECAPITULATION}

Summarizing, $P$. juglandis was preying on Juglans regia L. trees at the home-gardens and street-side stands, in Siedlce area. More numerous colonies of $P$. juglandis were observed on trees growing in street-side stand, where it formed colonies along the main vascular vein on the top part only of the first three external leaflets. 


\section{REFERENCES}

Amaral J.S., Casal S., Pereira J.A., Seabra R.M., Oliveira B.P.P. 2003. Determination of sterol and fatty acid compositions, oxidative stability, and nutritional value of six walnut (Juglans regia L.) cultivars grown in Portugal. J. Agric. Food Chem. 51, 7698-7702.

Amaral J.S., Alves M.R., Seabra R.M., Oliveira B.P.P. 2005. Vitamin E composition of walnuts (Juglans regia L.): a 3-year comparative study of different cultivars. J. Agric. Food Chem. 53, 5467-5472.

Amaral J.S., Valentão P., Andrade P.B., Martins R.C., Seabra R.M. 2008. Do cultivar, geographical location and crop season influence phenolic profile of walnut leaves? Molecules 13, 1321-1332.

Anderson K.J., Teuber S.S., Gobeille A., Cremin P., Waterhouse A.L., Steinberg F.M. 2001. Walnut polyphenolics inhibit in vitro human plasma and LDL oxidation. J. Nutr. 131, 2837-2842.

Barbagallo S., Binazzi A., Bolchi Serini G., Conci C., Longo S., Marotta S., Martelli M., Patti I., Pellizzari G., Rapisarda C., Russo A., Tranfaglia A. 1995. Homoptera Sternorrhyncha, in: Checklist delle specie della fauna italiana. Eds. A. Minelli, S. Ruffo, S. La Posta. Bologna, Calderini, 1-57.

Blackman R.L., Eastop V.F. 2000. Aphids on the World's Crops. An identification and information Guide. London, The Natural Museum.

Bruneton J. 1993. Pharmacognosie. Phytochimie. Plantes medicinales. Paris, Tec. \& Doc. Lavoisier.

Cai Y., Luo Q., Sun M., Corke H. 2004. Antioxidant activity and phenolic compounds of 112 traditional Chinese medicinal plants associated with anticancer. Life Sci. 74, 2157-2184.

Christopoulos M.V., Tsantili E. 2015. Oil composition in stored walnut cultivars - quality and nutritional value. Europ. J. Lipid Sci. Technol. 117, 338-348.

Chrzanowski G., Leszczyński B., Czerniewicz P., Sytykiewicz H., Matok H., Krzyżanowski R. 2011. Phenolic acids of walnut (Juglans regia L.). Herba Pol. 57(2), 22-29.

Cichocka E. 1980. Mszyce roślin sadowniczych. Warszawa, PWN, 119. [in Polish]

Cichocka E., Goszczyński W., Szybczyński K. 1998. Mszyce i ich naturalni wrogowie na klonach w Warszawie, w: Fauna miast. Red. T. Barczak, P. Indykiewicz. Bydgoszcz, Wydaw. ATR, 83-88. [in Polish]

Copolovici D., Bungău S., Boscencu R., Țiț D.M, Copolovici L. 2017. The fatty acids composition and antioxidant activity of walnut cold press oil. Rev. Chim. 68, 507-509.

Debach P. 1974. Biological control by natural enemies. London, Cambridge University Press.

Fukuda T., Ito H., Yoshida T. 2004. Effect of the walnut polyphenol fraction on oxidative stress in type 2 diabetes mice. Biofactors 21, 251-253.

Halbert S.E., Evans G.A., Clinton D.C., Nieto-Nafria J.M., Dixon A.F.G. 1998. Establishment of Taxoptera citricida in Florida. Aphids in natural and managed ecosystems, in: Proceedings of the Fifth International Symposium on Aphids. Leon, Spain, Universidad de Leon, 547-554.

Heie O.E. 1982. The Aphidoidea (Hemiptera) of Fennoscandia and Denmark. II. Fauna Entomologica Scandinavica 11. Leiden-Copenhagen: E.J. Brill/Scandinavian Science Pres.

Jakopic J., Colaric M., Veberic R., Hudina M., Solar A., Stampar F. 2007. How much do cultivar and preparation time influence on phenolics content in walnut liqueur? Food Chem. 104, 100-105.

Jakopic J., Solar A., Colaric M., Hudina M., Veberic R., Stampar F. 2008. The influence of ethanol concentration on content of total and individual phenolics in walnut alcoholic drink. Acta Aliment. 37, 233-239.

Jaśkiewicz B. 2003. Zdobniczka orzechowa (Panaphis juglandis Goethe) i zdobniczka podliściowa (Chromaphis juglandicola Kalt.) - mszyce obniżające dekoracyjność orzecha włoskiego [Large walnut aphid (Panaphis juglandis Goethe) and small walnut aphid (Chromaphis juglandicola Kalt.) - aphid reducing decorativeness of walnut]. Ochr. Rośl. 10, 17-18. [in Polish] 
Jaśkiewicz B., Cichocka E. 2004. Aphids on European Walnut (Juglans regia L.) in the urban conditions of Lublin, in: Aphids and other homopterous insects. Eds. E. Cichocka, W. Goszczyński, K. Wiech. Warszawa, PAN, 35-46.

Jaśkiewicz B., Kmieć K. 2007. The occurrence of Panaphis juglandis (Goetze) and Chromaphis juglandicola (Kalt.) on walnut under the urban condition of Lublin. Acta Sci. Pol., Hortorum Cultus 6 , $15-26$.

Karczmarz K. 2010. Numerical strength dynamics of Chromaphis juglandicola (Kalt. 1843) on common walnut (Juglans regia L.) in Lublin town plantings. Acta Sci. Pol., Hortorum Cultus 9, 121-132.

Karczmarz K. 2012. Dynamics of population and bionomics of Panaphis juglandis (Goetze) (Homoptera, Phyllaphididae) on common walnut (Juglans regia L.) in Lublin,s parks and gardens. Acta Sci. Pol., Hortorum Cultus 11, 53-70.

Krzyżanowski R. 2016. Wpływ lotnych związków orzecha włoskiego Juglans regia L. na zachowanie mszyc Panaphis juglandis (Goeze, 1778) i Chromaphis juglandicola (Kaltenbach, 1843). Siedlce, Wydaw. UPH. [in Polish]

Krzyżanowski R. 2017. Dynamika populacji i rozkład przestrzenny Chromaphis juglandicola (Kaltenbach, 1843) (Hemiptera: Phyllaphididae) na orzechu włoskim (Juglans regia L.) w ogrodach przydomowych i miejskich zadrzewieniach Siedlec [Population dynamics and spatial distribution of Chromaphis juglandicola (Kaltenbach, 1843) (Hemiptera: Phyllaphididae) on common walnut (Juglans regia L.) at home gardens and street tree plantings in Siedlce]. Prog. Plant Protec. 57(3), 211-218. [in Polish]

Leszczyński B., Matok H., Sytykiewicz H. 2012. Basic aspects of walnut allelopathy: From field to biomolecules. Saarbrücken, Lap Lambert Academic Publishing.

Lubiarz M. 2009. Domination structure of group of phytophagous hemipterous insects, aphids and scale insects on Quercus robur L. in natural and degraded landsape of the region of Lublin, in: Aphids and other homopterous insects. Ed. E. Cichocka. Warszawa, PAN, 133-150.

Milevoj L., Kravanja N. 1999. Health problems of trees in urban areas. Zbornik predavanj in referatov 4. Slovenskega Posvetovanja o varstvu rastlin v Portorozu. Ljubljana, Plant Prot. Soc. Slovenia 421-428.

Nieto Nafría J.M., Mier Durante M.P. 1998. Hemiptera, Aphididae, in: Fauna Iberica. Vol. 11. Ed. M.A. Ramos. Madrid, Spain, Museo Nacional de Ciencias Naturales, CSIC.

Nour V., Trandafir I., Cosmulescu S. 2013. HPLC Determination of phenolic acids, flavonoids and juglone in walnut leaves. J. Chromatogr. Sci. 51, 883-890.

Olson W.H. 1974. Dusky-veined walnut aphid studies. California Agric. 28(7), 18-19.

Park J.H., Gatewood B.M, Ramaswamy G.N. 2005. Naturally occurring quinines and flavonoid dyes for wool: insect feeding deterrents. J. Appl. Polym. Sci. 98, 322-328.

Petrovič O. 1998. Check-list of aphids (Homoptera: Aphididae) in Serbia. Acta Entomol. Serbica 3, 9-42.

Pollegioni P., Woeste K., Chiocchini F., Del Lungo S., Ciolfi M., Olimpieri I., Tortolano V., Clark J., Hemery G.E., Mapelli S., Malvolti M.E. 2017. Rethinking the history of common walnut (Juglans regia L.) in Europe: Its origins and human interactions. PLoS ONE 12(3), e0172541. DOI:10.1371/journal.pone.0172541.

Sabaté J., Fraser G.E., Burke K., Knutsen S., Bennett H., Lindsted K.D. 1993. Effect of walnuts on serum lipid levels and blood pressure in normal men. N. Engl. J. Med. 328, 603-607.

Szelęgiewicz H. 1972. Zapiski afidologiczne z Babiej Góry (Homoptera, Aphidodea) [Notes from Babia Gora (Homoptera, Aphidodea)]. Fragm. Faun. 18, 205-243. [in Polish]

Tsamourisa G., Hatziantonioub S., Demetzosa C. 2002. Lipid analysis of greek walnut oil (Juglans regia L.). Z. Naturforsch. 57, 51-56.

Wani S.A., Ahmad S.T. 2014. Competition and niche-partitioning in two species of walnut aphids. Inter. J. Sci. Res. Rev. 3, 120-125. 
Wilkaniec B. 1999. Studies of bionomy and ecology of large walnut aphid, Callaphis juglandis (Goetz.) (Homoptera, Phyllaphididae) on walnut tree. Ann. Agric. Sci. Ser. E Plant Protection 28, 37-43.

\begin{abstract}
Common walnut (Juglans regia L.) has gained recognition in Poland as an ornamental species in city environments. More frequent use of walnut in the city landscape has induced a more thorough analysis of the factor that causes a significant decrease in the decorative values of this tree. The aim of this paper was to trace population dynamics and spatial distribution of Panaphis juglandis (Goeze 1778) occupying the J. regia trees. The studies were conducted on walnut trees (J. regia) in Siedlce in the years 2010-2012. Three tree stands in home gardens were selected for observation $(\mathrm{H} 1, \mathrm{H} 2, \mathrm{H} 3)$ and one near the street $(\mathrm{H} 4)$. Results showed that higher aphid population was found on the studied tree at the street stand in relation to the home gardens trees. $P$. juglandis were observed on trees growing in street-side stand, where it formed colonies along the main vascular vein on the top part only of the first three external leaflets.
\end{abstract}

The research was carried out under the research project No. 245/08/S financed by the Polish Ministry of Science and Higher Education. 